\title{
XP01 Gene
}

National Cancer Institute

\section{Source}

National Cancer Institute. XPO1 Gene. NCI Thesaurus. Code C99484.

This gene plays a role in the regulation of nuclear export. 